\title{
FACTORS AFFECTING THE USE OF PERSONAL PROTECTIVE EQUIPMENT AMONG WORKERS AT A PLYWOOD PLANTS, IN LUMAJANG, EAST JAVA: APPLICATION OF HEALTH BELIEF MODEL AND SOCIAL COGNITIVE THEORY
}

\author{
Bayu Putra Dewantara'), Bhisma Murti'), Vitri Widyaningsih²) \\ 1)Masters Program in Public Health, Universitas Sebelas Maret \\ ${ }^{2)}$ Faculty of Medicine, Universitas Sebelas Maret
}

\begin{abstract}
Background: By products of wood processing such as wood dust and noise are well known with respect to occupational health effects in workers at plywood plants. Previous studies suggested that workers in sawmills, plywood/particle board factories, and veneer plants are at risk of developing allergenic disorders, lung disease, and cancer. Employers have duties concerning the provision and use of personal protective equipment (PPE) at work. PPE is equipment that will protect the user against the risk of accidents or of adverse effects on health. This study aimed to investigate factors affecting the use of personal protective equipment among workers at a plywood plants.

Subjects and Method: A cross-sectional study was conducted in Lumajang, East Java, in December 2019. A sample of 200 workers was selected randomly. The dependent variable was the use of PPE. The independent variables were motivation, training, attitude, outcome expectation, perceived benefit, vicarious experience, observational learning, regulatory compliance, and reinforcement. The data were collected by questionnaire and analyzed by a multiple logistic regression.

Results: The use PPE increased with high motivation (OR=7.00; 95\% CI= 1.46 to 33.54; $\mathrm{p}=0.015)$, had trained $(\mathrm{OR}=22.56 ; 95 \% \mathrm{CI}=3.43$ to $148.35 ; \mathrm{p}=0.001)$, positive attitude $(\mathrm{OR}=8.66 ; 95 \% \mathrm{CI}=1.71$ to $43.84 ; \mathrm{p}=0.009)$, high outcome expectation $(\mathrm{OR}=5.71 ; 95 \%$ $\mathrm{CI}=0.83$ to $39.02 ; \mathrm{p}=0.075)$, high perceived benefit $(\mathrm{OR}=8.60 ; 95 \% \mathrm{CI}=1.63$ to $45.32 ; \mathrm{p}=$ o.011), vicarious experience $(\mathrm{OR}=16.89 ; 95 \% \mathrm{CI}=3.13$ to $91.01 ; \mathrm{p}=0.001)$, observational learning $(\mathrm{OR}=25.78$; $95 \% \mathrm{CI}=4.36$ to 152.54 ; $\mathrm{p}<0.001)$, compliance to regulation $(\mathrm{OR}=$ $5.80 ; 95 \% \mathrm{CI}=0.93$ to $35.83 ; \mathrm{p}=0.058)$, and reinforcement $(\mathrm{OR}=4.83 ; 95 \% \mathrm{CI}=1.14$ to 20.47; $\mathrm{p}=0.032$ ).

Conclusion: The use PPE increases with high motivation, had trained, positive attitude, high outcome expectation, high perceived benefit, vicarious experience, observational learning, compliance to regulation, and reinforcement.
\end{abstract}

Keywords: personal protective equipment, health belief model, social cognitive theory

\section{Correspondence:}

Bayu Putra Dewantara. Masters Program in Public Health, Universitas Sebelas Maret. Jl. Ir. Sutami 36A, Surakarta 57126, Central Java, Indonesia. Email: bayuputradewantara@gmail.com. Mobile: +6281352347536.

The $7^{\text {th }}$ International Conference on Public Health Solo, Indonesia, November 18-19, $2020 \mid 161$ https://doi.org/10.26911/the7thicph.02.50 